\title{
NEW RECORDS OF GREY CUTTHROAT, SYNAPHOBRANCHUS AFFINIS (ACTINOPTERYGII: ANGUILLIFORMES: SYNAPHOBRANCHIDAE) FROM THE EASTERN-CENTRAL ATLANTIC OCEAN
}

\author{
Armando J. ALMEIDA ${ }^{1}$, Manuel BISCOITO ${ }^{2 *}$, José I. SANTANA ${ }^{3}$, and José A. GONZÁLEZ ${ }^{3}$ \\ ${ }^{1}$ Universidade de Lisboa, Faculdade de Ciências, DBA, Centro de Oceanografia, \\ Laboratório Marítimo da Guia, Cascais, Portugal \\ ${ }^{2}$ Museu Municipal do Funchal (História Natural), Estação de Biologia Marinha do Funchal - IMAR, \\ Funchal, Madeira, Portugal \\ ${ }^{3}$ Instituto Canario de Ciencias Marinas, Departamento de Biología Pesquera, Telde, Las Palmas, Spain
}

Almeida A.J., Biscoito M., Santana J.I., González J.A. 2010. New records of grey cutthroat, Synaphobranchus affinis (Actinopterygii: Anguilliformes: Synaphobranchidae), from the eastern-central Atlantic Ocean. Acta Ichthyol. Piscat. 40 (1): 66-70.

\begin{abstract}
Following a series of surveys with bottom longlines and fish traps along the island slopes off the archipelagos of Madeira, Canaries and Cape Verde, and with bottom trawls along the coast of Morocco and Western Sahara between 2004 and 2006 many specimens of Synaphobranchus were caught, revealing the presence of two species. Based on these specimens and Museum preserved specimens from this area grey cutthroat, Synaphobranchus affinis Günther, 1877, is recorded for the first time from off Portugal, Madeira archipelago, Great Meteor Seamount, Canary Islands, Morocco, Western Sahara, Cape Verde Islands, and Senegal. It is confirmed that $S$. kaupii is also conspecific in this area. Meristic and morphometric data of the specimens studied are also presented.
\end{abstract}

Keywords: Synaphobranchus, Portugal, Madeira, Canary Islands, Cape Verde Islands, Great Meteor Seamount, NW Africa, distribution

The genus Synaphobranchus is represented by three species in the central and eastern North Atlantic Ocean: Kaup's arrowtooth eel, S. kaupii Johnson, 1862; grey cutthroat, S. affinis Günther, 1877; and shortdorsal cutthroat eel, S. brevidorsalis Günther, 1877 (see: Sulak and Shcherbachev 1997, Almeida and Biscoito 2007). Until the new records from the Azores (Almeida and Biscoito 2007), $S$. kaupii was the only species of this genus recorded North of $10^{\circ} \mathrm{N}$, in the eastern Atlantic, except for a single record of $S$. affinis from the Strait of Gibraltar (Sulak and Shcherbachev 1997).

During a series of captures with bottom longlines and fish traps along the slopes of the islands of Madeira and Porto Santo, Seine and Unicorn Seamounts (Madeira), Gran Canaria (Canaries), Boavista and Santiago (Cape Verde), and with bottom trawls along the coast of Morocco and Western Sahara (Fig. 1), a large number of specimens of Synaphobranchus were caught and deposited in the Museu Municipal do Funchal (História Natural) (MMF) and Museo de Ciencias Naturales de Tenerife (TFMC-BM). A detailed study of these collections, together with others deposited in the Natural History Museum, London (BMNH), the Muséum national d'Histoire naturelle, Paris (MNHN) and Institut de Ciències del Mar, Barcelona (IIPB), led to the discovery of specimens of $S$. affinis, a species not previously recorded from the above mentioned areas and which is reported herein.

Three hundred and ninety-two specimens of Synaphobranchus spp. from the south-western coast of Portugal, the archipelago of Madeira (including the Seine and Unicorn seamounts), the Great Meteor Seamount, the Canary and Cape Verde islands, and from the Atlantic coast of Morocco and Western Sahara, down to Angola (Fig. 1) were examined in the collections of MMF, TFMC-BM, BMNH, MNHN, and IIPB. The RRS DISCOVERY specimens examined at the Natural History Museum, London, form a part of a larger collection that has already been reported (Merrett and Marshall 1981, Merrett and Domanski 1985). Some old specimens in the MMF labelled as "from Madeira" bear no other collection details and, according to G. E. Maul (personal communication 1981), they were brought to the Museum by the

\footnotetext{
${ }^{*}$ Correspondence: Dr. Manuel José Biscoito, Curator of Ichthyology, Museu Municipal do Funchal (História Natural)/Estação de Biologia Marinha do Funchal, Cais do Carvão - Promenade da Orla Maritima do Funchal, Gorgulho, 9000-107 Funchal, Madeira, Portugal, phone: +351 291700360 , fax: +351 291 766339; e-mail: manuel.biscoito@cm-funchal.pt.
} 


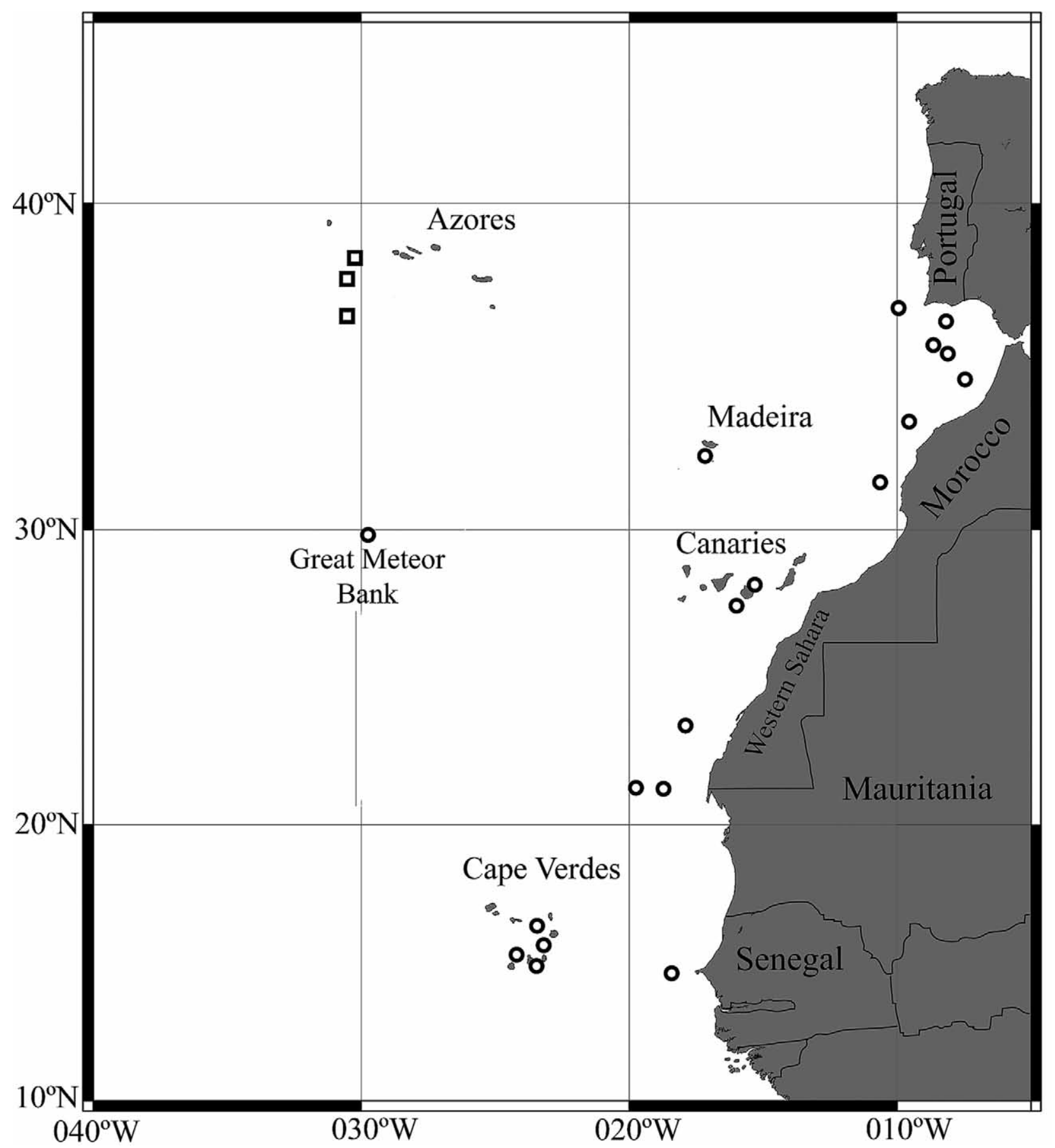

Fig. 1. Collection locations of Synaphobranchus affinis. New records (circles) and records from Almeida and Biscoito (2007) (squares)

local black-scabbardfish fishermen and therefore were definitely caught in the waters around Madeira.

Whenever possible, four point-to-point measurements (total length, TL; predorsal length, PD; preanal length, PA; and length of pectoral fin, PL) were made to the millimetre (mm) following Saldanha and Merrett (1982). Forty-five specimens were x-rayed and total vertebral counts made. The shape and distribution of the body scales at level of anus, above and below the lateral line, and their presence or absence on the interradial membrane of anal fin were observed in each specimen as well as the number, distribution and size of the teeth on the premaxillary-ethmoid complex (PME) and on the vomer.

Of the 392 specimens studied, 291 evidently belong to S. kaupii and 101 to $S$. affinis. One leptocephalus larva assigned to $S$. kaupii by Maul (1976) (MMF 22475x) was not studied.

\section{Synaphobranchus affinis Günther, 1877}

Misidentifications: Synaphobranchus kaupi: Maul 1976: 18 (in part); Uiblein et al. 1999: 61, Appendix, Plate II (9).

Material examined (number of specimens in parenthesis): BMNH 1853.11.29-24, (1), no data, 1853, Madeira, 
602 mm TL. BMNH 1858.4.4.3, (1), no data, 1858, Madeira, $735 \mathrm{~mm}$ TL. BMNH 1995.6.1:78, (1), 31 ${ }^{\circ} 25^{\prime} \mathrm{N}$, $10^{\circ} 53^{\prime} \mathrm{W}, 02.08 .1976,1181 \mathrm{~m}$, off Canary Is., $452 \mathrm{~mm}$ TL. MMF 71, (1), no data, Madeira, damaged. MMF 2405, (1), Madeira, 626 mm TL. MMF 2672, (1), no data, 1941, Madeira, Câmara de Lobos, damaged. MMF 3402, (1), no data, Madeira, damaged. MMF 3438, (1), Madeira, $624 \mathrm{~mm}$ TL. MMF 3824, (1), Madeira, $801 \mathrm{~mm}$ TL. MMF 3825, (1), Madeira, $417 \mathrm{~mm}$ TL. MMF 15108, (1), Madeira, Câmara de Lobos, 514 mm TL. MMF 22475-G, $\mathrm{L}, \mathrm{M},(3), 33^{\circ} 12^{\prime} \mathrm{N}, 9^{\circ} 15^{\prime} \mathrm{W}, 1967,500 \mathrm{~m}$, Morocco,

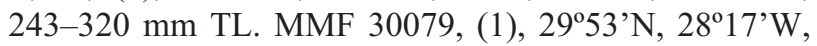
1998, 800 m, Great Meteor Seamount, 568 mm TL. MMF 33598, (1), 32 $36.1^{\prime} \mathrm{N}, 16^{\circ} 53.5^{\prime} \mathrm{W}, 2000,800 \mathrm{~m}$, Madeira, Bay of Funchal, $603 \mathrm{~mm}$ TL. MMF 35096, (1), $32^{\circ} 36.5^{\prime} \mathrm{N}, 16^{\circ} 53.5^{\prime} \mathrm{W}, 2000,500 \mathrm{~m}$, Madeira, Bay of Funchal, damaged. MMF 35097, (1), 32 $36.5^{\prime} \mathrm{N}$, $16^{\circ} 53.5^{\prime} \mathrm{W}, 2000,600 \mathrm{~m}$, Madeira, Bay of Funchal, 531 mm TL. MMF 35618-21, (4), 32³6.14'N, $16^{\circ} 52.76^{\prime} \mathrm{W}$, 25-02-2004, 1000 m, Madeira, Bay of Funchal, 534-695 mm TL. MMF 35631-33, (3), 32 $36.16^{\circ} \mathrm{N}, 16^{\circ} 54.06^{\prime} \mathrm{W}$, 26-02-2004, 1000 m, Madeira, Bay of Funchal, 547-840 mm TL. MMF 35634-39, (6), 27 $38.8^{\prime} \mathrm{N}, 15^{\circ} 49.5^{\prime} \mathrm{W}, 22-$ 11-2003, 1408 m, Canary Is., Arguineguin, 437-708 mm TL. MMF 35968-70, 74, 77, 80, (6), 3345.5' N, $14^{\circ} 29.8^{\prime} \mathrm{W}, 2004,1000 \mathrm{~m}$, Seine Seamount, 496-730 mm TL. MMF 36033, (1), 32º58.9'N, $16^{\circ} 26.3^{\prime} \mathrm{W}, 2004,1000$ $\mathrm{m}$, Porto Santo, I. de Fora, 476 mm TL. MMF 36035, (1), $34^{\circ} 35.7^{\prime} \mathrm{N}, 1^{\circ} 28.8^{\prime} \mathrm{W}, 2004,1500 \mathrm{~m}$, Unicorn Seamount, $600 \mathrm{~mm}$ TL. MMF 36104, (1), 34 $30.9^{\prime} \mathrm{N}, 1^{\circ} 27^{\prime} \mathrm{W}$, 2004, 2000 m, Unicorn Seamount, 587 mm TL. MMF 36132, (1), 3309.8' N, 16 ${ }^{\circ} 16.4^{\prime} \mathrm{W}, 31-08-2004,1000 \mathrm{~m}$, Porto Santo, $522 \mathrm{~mm}$ TL. MMF 36133, (1), 33ํ03.6'N, $16^{\circ} 18.9^{\prime} \mathrm{W}, 28-08-2004,500 \mathrm{~m}$, Porto Santo, $382 \mathrm{~mm}$ TL.

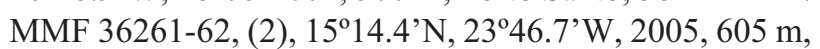
Cape Verde Is. (Santiago, Tarrafal), 446-639 mm TL.

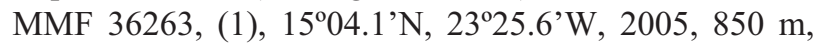
Cape Verde Is. (Santiago, A Baleia), $570 \mathrm{~mm}$ TL. MMF 36264, (1), 15 $54.4^{\prime} \mathrm{N}, 22^{\circ} 51^{\prime} \mathrm{W}, 2005,602 \mathrm{~m}$, Cape Verde Is. (Boavista, Tarafe) $386 \mathrm{~mm}$ TL. MMF 36479,

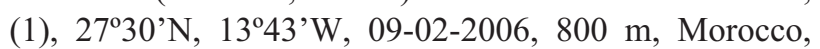
$385 \mathrm{~mm}$ TL. MMF 36500-02, (2), 32 $40.3^{\prime} \mathrm{N}, 16^{\circ} 44.7^{\prime} \mathrm{W}$, 2005, 800 m, Madeira, Santa Cruz, 598-622 mm TL. MMF 36569, (1), 32 $52^{\circ} \mathrm{N}, 17^{\circ} 00.7^{\prime} \mathrm{W}, 2005,750 \mathrm{~m}$, Madeira, Ponta Delgada, $656 \mathrm{~mm}$ TL. MMF 36576, (1), $33^{\circ} 00.8^{\prime} \mathrm{N}, 16^{\circ} 11.8^{\prime} \mathrm{W}, 2005,1500 \mathrm{~m}$, Porto Santo, 645

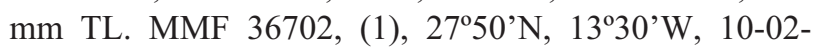
2006, 849 m, Western Sahara, 610 mm TL. MNHN 1965-

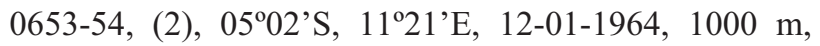
Congo, Pointe Noire, 372-517 mm TL. MNHN 1974-

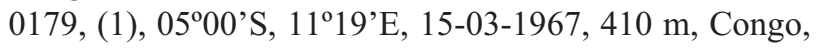
Pointe Noire, $231 \mathrm{~mm}$ TL. MNHN 1974-0180A, B, (2), 02³0'S, 0852'E, 05-09-1963, 400 m, Congo, 278-346

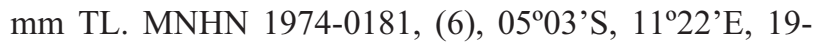
09-1967, 400 m, Congo, 240-308 mm TL. MNHN 1974-

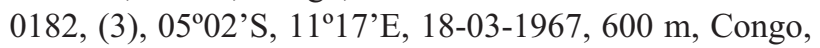
345-390 mm TL. MNHN 1974-0183, (4), 04²4'S, $11^{\circ} 25^{\prime} \mathrm{E}, 04-1973,600 \mathrm{~m}$, Congo, Pointe Noire, 330-430 mm TL. MNHN 1974-0185A, B, (2), 0504'S, 10¹3'E, 17-03-1967, $805 \mathrm{~m}$, Congo, Pointe Noire, 422-508 mm TL. MNHN 1974-0220, (13), 05'02'S, $11^{\circ} 15^{\prime} \mathrm{E}, 17-03-$ 1967, $600 \mathrm{~m}$, Congo, Pointe Noire, 262-425 mm TL.

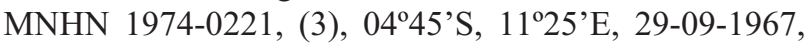
$800 \mathrm{~m}$, Congo, Pointe Noire, 445-572 mm TL. MNHN 1987-0995, (1), 03²28'S, 09²8' E, 1980, Congo, $590 \mathrm{~mm}$

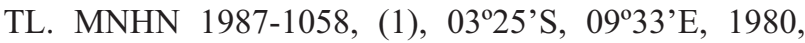
$1030 \mathrm{~m}$, Congo, $444 \mathrm{~mm}$ TL. MNHN 1987-1529, (1), $14^{\circ} 21^{\prime} \mathrm{N}, 17^{\circ} 38^{\prime} \mathrm{W}, 1981$, Senegal, $482 \mathrm{~mm}$ TL. MNHN 1987-1553, (1), 02041'S, 0851'E, 1980, 915 m, Congo, $455, \mathrm{~mm}$ TL. MNHN 1988-0518, (1), 36 $48^{\circ} \mathrm{N}, 09^{\circ} 28^{\prime} \mathrm{W}$, 1984, 1192 m, Portugal, off Sagres, 436, mm TL. MNHN

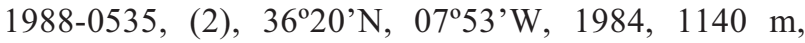
Morocco, 455-590 mm TL. MNHN 2001-0098, (1), $07^{\circ} 22^{\prime} \mathrm{S}, 11^{\circ} 31^{\prime} \mathrm{E}, 25-08-2000,1289 \mathrm{~m}$, Angola, damaged. MNHN 2006-1523, (1), 34² $21^{\prime} \mathrm{N}, 07^{\circ} 24^{\prime} \mathrm{W}, 1984$, $895 \mathrm{~m}$, Morocco, $465 \mathrm{~mm}$ TL. MNHN 2006-1524, (1), $20^{\circ} 41^{\prime} \mathrm{N}, 18^{\circ} 33^{\prime} \mathrm{W}, 1991,2114 \mathrm{~m}$, Off Cape Blanc, 546

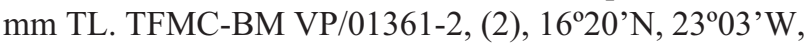
2005, 680 m, Cape Verde Is. (Boavista, P. Sol), 308-455 $\mathrm{mm}$ TL. TFMC-BM VP/01578, (1), 30 $53^{\circ} \mathrm{N}, 10^{\circ} 33^{\prime} \mathrm{W}$, 06-12-2005, $1057 \mathrm{~m}$, Morocco, $292 \mathrm{~mm}$ TL.

Morphometric and meristic data of the specimens studied are as follows (number of specimens in parenthesis). In percent of total length: HL: 9.8-14.2 (49); PD: 26.2-36.8 (63); PA: 25.5-39.0 (62); PL: 3.9-6.7 (61). In percent of head length: Snout: 25.3-37.7 (52); Jaw: 41.9-69.0 (51); Eye diameter: 4.5-18.0 (51). Total vertebrae: 131-150 (25). All specimens studied agree well with the descriptions and data given by Karrer (1982), Robins and Robins (1989), and Sulak and Shcherbachev (1997). In the specimens measured, the origin of dorsal fin varied considerably from well behind to slightly in advance of the origin of anal fin, as shown by the variation of PD-PA (11.0-39.0). However, taking the mode, the origin of dorsal fin in our specimens of $S$. affinis is always closer to the origin of anal fin ((PD-PA)/PL $=0.7-1.0)$.

Distribution. In the north-eastern Atlantic S. affinis was known by rare records (Sulak and Shcherbachev 1997, Almeida and Biscoito 2007). It is now recorded for the first time from off southern Portugal south to Senegal, including the archipelagos of Madeira, Canaries and Cape Verde and the Great Meteor Seamount (Fig. 1). The specimens examined were caught between $400 \mathrm{~m}$ and $2114 \mathrm{~m}$ of depth.

As pointed out by Sulak and Shcherbachev (1997), the identification of the species of Synaphobranchus is often technically challenging, especially with damaged specimens or in the absence of comparative material. In the course of the present study, the main diagnostic character used to separate the three species was the arrangement of the teeth in the premaxillary-ethmoid complex (PME). The relative position of the dorsal fin origin in relation to the anal fin origin proved to be a useful character separating, in most cases, $S$. affinis from $S$. kaupii. However, the large variation observed in some specimens, which is more important than the one reported by Matsubara and Ochiai (1951) for specimens from Japan and is similar to 
the one found by Blache (1972) in specimens from off Congo, necessitated the complementary observation of the teeth in the PME, in order to arrive to a definite identification.

Meristic and morphometric data obtained from the present study enlarge the ranges previously published by Almeida and Biscoito (2007), in particular the eye diameter in $\%$ of head length (4.5-18.0 vs. 9.9-13.5). This may be explained not only by the much larger sample used in the present study, but also due to an extension in the size range of the specimens studied.

The scales form and pattern, characters that have been used by several authors to differentiate these species, were also found useful, but only when used on well preserved adult specimens and in the presence of comparative material. In our specimens of $S$. affinis, the interradial membrane of the anal fin always beard scales, even at its origin, a character also noted in the specimens studied by Karrer (1982).

The new records of $S$. affinis reported herein not only represent the more northerly ones in the eastern Atlantic Ocean, but also fill a noticeable gap in the distribution of this species between $14^{\circ} \mathrm{N}$ and the Gibraltar parallel (Fig. 1). This new distribution is most probably due to $S$. affinis has been misidentified as $S$. kaupii, a species now known to be sympatric. S. affinis has proved to have a continuous distribution along the tropical and subtropical eastern Atlantic. However, preliminary data obtained by us seem to indicate that both species are not equally abundant in the areas studied, a situation already noted by Sulak and Shcherbachev (1997). Captures with bottom fish traps in the waters of Madeira, the Canary and the Cape Verde Islands seem to be largely dominated by $S$. affinis (a study on the species' relative abundance and depth distribution is under way and its results will be published elsewhere).

\section{ACKNOWLEDGEMENTS}

The authors are indebted to Concepción Allué, Ricardo Araújo, Mikel Arrasate, Ana Luisa Costa, João Delgado, Rosa Domínguez-Seoane, Francisco Fernandes, Mafalda Freitas, Antonio M. García-Mederos, Ignacio J. Lozano, Catarina Malheiro, José A. Pérez-Peñalvo, Ana Rita Pinto, João Silva and Víctor M. Tuset for the handling of the specimens on board and at the laboratory and the crews of $R / V A R Q U I P E L A G O, R / V$ PIXAPE II, F/V BAÍA DE CÂMARA DE LOBOS, F/V MARY NERE, F/V FARRUCO, F/V MYRDOMA F, F/V FULA, and F/VMAR ROJO DOS. Thanks are also due to Nigel Merrett and Emma Karmovskaya for the critical reading of the manuscript and very useful comments and suggestions.

This work was made possible through funds obtained from the European Union, the Foundation for Science and Technology (Portugal), Spanish Ministry for Fisheries (pilot projects APE 36 and 37/2005) and the Regional Governments of the Canary Islands and Madeira. Most specimens were obtained under the framework of the European Programme INTERREG III B
(Açores-Madeira-Canárias), Projects PESCPROF-1 and 2 (MAC/4.2/M12 and 05/MAC/4.2/M11), HYDROCARPO (MAC/4.2/C5).

This paper is contribution No. 16 of the Marine Biological Station of Funchal.

\section{REFERENCES}

Almeida A.J., Biscoito M. 2007. New records of Synaphobranchus (Anguilliformes, Synaphobranchidae) from off the Azores (eastern Atlantic Ocean). Cybium 31 (2): 391-392.

Blache J. 1972. Contribution à la connaissance des poisons Anguilliformes de la côte occidentale d'Afrique. $14^{\mathrm{e}}$ note: la famille des Synaphobranchidae. Bulletin de l' IFAN A 34: 966-973.

Karrer C. 1982. Anguilliformes du Canal de Mozambique (Pisces, Teleostei). Faune Tropicale 23: 1-115.

Matsubara K., Ochiai A. 1951. Notes on the eels of the genus Synaphobranchus found in Japanese waters. Japanese Journal of Ichthyology 1: 251-259.

Maul G.E. 1976. The fishes taken in bottom trawls by R.V. "Meteor" during the 1967 seamounts cruises in the Northeast Atlantic. "Meteor" Forschungs-Ergebnisse, Reihe D 22: 1-69.

Merrett N.R., Domanski P.A. 1985. Observations on the ecology of deep-sea bottom-living fishes collected off northwest Africa: II. The Moroccan slope $\left(27^{\circ}-34^{\circ} \mathrm{N}\right)$, with special reference to Synaphobranchs kaupi. Biological Oceanography 3: 349-399.

Merrett N.R., Marshall N.B. 1981. Observations on the ecology of deep-sea bottom-living fishes collected off northwest Africa $\left(08^{\circ}-27^{\circ} \mathrm{N}\right)$. Progress in Oceanography 9 (4): $185-244$.

Robins C.H., Robins C.R. 1989. Family Synaphobranchidae. Pp. 207-253. In: Böhlke E.B. (ed.) Fishes of the western North Atlantic. Part 9. Orders Anguilliformes and Saccopharyngiformes. Sears Foundation for Marine Research, Yale University, New Haven CT.

Saldanha L., Merrett N.R. 1982. A new species of the deepsea eel genus Ilyophis Gilbert (Synaphobranchidae) from the eastern North Atlantic, with comments on its ecology and intrafamilial relationships. Journal of Fish Biology 21 (6): 623-636. DOI: 10.1111/j.1095-8649.1982.tb02866.x.

Sulak K.J., Shcherbachev Yu.N. 1997. Zoogeography and systematics of six deep-living genera of synaphobranchid eels, with a key to taxa and description of two new species of Ilyophis. Bulletin of Marine Science 60: 1158-1194.

Uiblein F., Geldmacher A., Köster F., Nellen W., Kraus G. 1999. Species composition and depth distribution of fish species collected in the area of the Great Meteor Seamount, eastern central Atlantic, during cruise M42/3, with seventeen new records. Informes Técnicos del Instituto Canario de Ciencias Marinas 5: 49-79.

Received: 27 November 2008 Accepted: 28 May 2009 Published electronically: 25 June 2010 